\title{
REVIEW
}

\section{INVOLVEMENT OF C4 ALLOTYPES IN THE PATHOGENESIS OF HUMAN DISEASES}

\author{
Eliana Sueco Tibana Samano, Lia de Melo Ribeiro, Rosa G. Gorescu, Katya \\ Cristina Rocha and Anete S. Grumach
}

SAMANO EST et al. Involvement of C4 allotypes in the pathogenesis of human diseases. Rev. Hosp. Clín. Fac. Med. S. Paulo 59(3):138-144, 2004.

The complement system is an important humoral defense mechanism that plays a relevant role against microbial agents, inflammatory response control, and immunocomplex clearance. Classical complement pathway activation is antibodydependent. The $\mathrm{C} 4$ component participates in the initial step of activation, and $\mathrm{C} 4$ expression is determined by 2 pairs of allotypes: C4A and C4B. Deficiencies in $\mathrm{C} 4$ allotypes have been associated with several diseases.

The aim of the present review is evaluate the reported data in the literature regarding specific $\mathrm{C} 4 \mathrm{~A}$ and $\mathrm{C} 4 \mathrm{~B}$ deficiencies and characterize their clinical relevance.

We searched the MEDLINE and LILACS databases. Papers referring to total C4 deficiency without allotype evaluation and case reports of primary $\mathrm{C} 4$ deficiency were not included.

Deficiencies in C4 allotypes have been associated with Mycobacterium leprae infection, erythema nodosum, systemic sclerosis with anti-topoisomerase I antibodies, intermediate congenital adrenal hyperplasia with DR5 genotype, diabetes mellitus type 1 with DR3,4 genotype, and diabetes mellitus with antibodies against islet cells. C4 allotype deficiency is also related to $\mathrm{C} 4 \mathrm{~B}$ deficiency and autoimmune-associated diseases, such as systemic lupus erythematosus, or diseases with an autoimmune component, such as autism. Some reports associate C4A with thyroiditis after delivery as well as limited and systemic sclerosis without anti-topoisomerase I antibodies. However, the studies with C4A and C4B have been concentrated in isolated populations, and some of the studies could not be reproduced by other authors.

KEY WORDS: C4 allotypes. C4A. C4B. C4. Complement. Complement deficiency.

The complement system is comprised of at least by 30 proteins, ${ }^{7}$ forming an important mechanism of humoral defense by the immune system. It activates in defense against microbial agents, in the control of the immune response, and in the clearance of immune complexes. It can be activated by 3 pathways: classic, alternative, and by lectins.

The classic pathway depends on the presence of antibody. Therefore, it is an effector system of high specificity. Viruses, DNA, C-reactive protein, and mitochondrial membranes can activate this pathway, independent of the antibody. Furthermore, fungi, polysaccharides, viruses, and cells infected by viruses can activate the pathway directly. The lectin pathway may be initiated by the linkage of mannanbinding lectin (MBL) to mannose and $\mathrm{N}$-acetyl-glucosamine residues on surfaces of microorganisms. When MBL binds to these sugars, they activate the

From the Laboratory of Medical Investigation in Clinical Allergy and Immunology, Hospital das Clínicas, Faculty of Medicine, University of São Paulo - São Paulo/SP, Brazil.

E-mail: grumach@usp.br Received for publication on September 02, 2003. serine proteases of mannose (MASP-1 and MASP-2). After that, $\mathrm{C} 4$ is cleaved into $\mathrm{C} 4 \mathrm{a}$ and $\mathrm{C} 4 \mathrm{~b}$, and $\mathrm{C} 2$ into $\mathrm{C} 2 \mathrm{a}$ and $\mathrm{C} 2 \mathrm{~b}$. All the pathways converge to $\mathrm{C} 3$ activation, and consequently, the membrane attack complex (MAC) $)^{2}$ is formed.

Receptors for the complement system components are largely distributed on the surface of tissue and blood cells. In addition to the mediated cytolysis by MAC, the action of complement is mediated by 3 products that are generated during the activation of ligands by specific receptors that act in several cells. The regulation of the 
complement system is controlled by a group of plasma proteins, and cells use these regulator proteins, which are located on their membranes, to defend themselves from the MAC systems.

Most of the complement proteins are produced in the liver; nevertheless, some other cells, such as monocytes, $\mathrm{T}$ cells, macrophages, granulocytes, skin fibroblasts, and keratinocytes that produce $\mathrm{C} 3$, can also synthesize these components. ${ }^{2,3}$

The complement system is important to host biological defense, as is evident when patients with complement component deficiencies show an increased predisposition for infections and diseases.

The $\mathrm{C} 4$ molecule $(204 \mathrm{kDa})$ is produced in the liver, and its concentration in the plasma is about $75 \mathrm{mg} / \mathrm{mL}^{2}$. This molecule is synthesized as a single chain and then is processed into 3 polypeptide chains $(\alpha, \beta, \gamma)$. The $\alpha$ chain has an intramolecular thioester bond. $\mathrm{C} 4$ is cleaved by $\mathrm{C} 1 \mathrm{~s}$, forming $\mathrm{C} 4 \mathrm{a}$ and $\mathrm{C} 4 \mathrm{~b}$. This reaction allows a covalent binding between the activated protein and the cellular surface or the receptor molecule. ${ }^{2}$

The expression of $\mathrm{C} 4$ is determined by 2 allotypes: $\mathrm{C} 4 \mathrm{~A}$ and $\mathrm{C} 4 \mathrm{~B}$. They are coded by 2 adjacent genes that are located on the short arm of chromosome 6 . These genes are close to genes that code for the enzyme 21-hydroxylase (21-OH), the $\mathrm{C} 2$ component, and the $\mathrm{B}$ factor (Bf), all of which are components of the major histocompatibility complex class III (MHC class III) $)^{2,4}$ (Figure 1).

The $\mathrm{C} 4$ fraction is one of the most polymorphic molecules of the MHC class III, with about 35 allotypes having been described. ${ }^{5} \mathrm{C} 4$ polymorphism is important for binding the large diversity of antigen-antibody complexes.

At the primary response, recognition of the antigen by the antibody is amplified by the classic pathway of complement activation, in which the cleavage of $\mathrm{C} 4$ into $\mathrm{C} 4 \mathrm{a}$ and $\mathrm{C} 4 \mathrm{~b}$ by $\mathrm{C} 1$ are some of the first steps. The binding efficiency depends on the $\mathrm{C} 4$ allotype and the nature of the antigen or antibody molecule. The $\mathrm{C} 4 \mathrm{~b}$ fraction from the $\mathrm{C} 4 \mathrm{~A}$ allotype preferentially binds amide groups to amino groups, while $\mathrm{C} 4 \mathrm{~b}$ from $\mathrm{C} 4 \mathrm{~B}$ makes ester bonds using carbohydrates or hydroxyl groups from amino acids (serine, threonine, tyrosine). This selectivity seems to be related to the electrostatic and stereochemical interactions between the isotypic regions of the C4's a chain and the receptor molecule. ${ }^{5,2,6}$ This $\mathrm{C} 4$ polymorphism also suggests an important involvement in the autoimmune diseases. ${ }^{6}$

The $\mathrm{C} 4 \mathrm{~A}$ and $\mathrm{C} 4 \mathrm{~B}$ allotypes have $90 \%$ homology. At the a chain region called C4d, there are 4 amino acids at positions 1101 to 1106 that are responsible for the structural and functional differences of the 2 allotypes. ${ }^{5}$

The aim of the present study is to partial deficiency of $\mathrm{C} 4$ and to evaluate the papers that associate human diseases with specific deficiencies of the $\mathrm{C} 4$ allotypes.

We performed an extensive literature review of the last 10 years using the MEDLINE and LILACS databases. Publications associated with $\mathrm{C} 4$ defidescribe the clinical significance of a

\section{METHOD}

ciency allotypes and human diseases were included. Furthermore, the key words $C 4$ allotypes and diseases were used. We excluded papers concerning a primary deficiency with total absence of $\mathrm{C} 4$ (C4 congenital deficiency), which are very rare in the medical literature. Studies about C4 deficiency without the allotype evaluation were also not considered.

\section{RESULTS}

Deficiencies in $\mathrm{C} 4$ allotypes that are associated with human diseases and the methodology applied for determining the plasma levels complement components or allotype genotyping are shown on Table 1 .

\section{Total deficiency of $\mathrm{C} 4$ and its allotypes}

Complement deficiency, in particular of the $\mathrm{C} 4$ fraction, has been the subject of studies of several human diseases. Deficiencies in $\mathrm{C} 4$ allotypes occur in $0.1 \%$ to $0.3 \%$ of the population as result of deletion, genetic conversion, or silent mutations. ${ }^{5} \mathrm{C} 4$ deficiencies have been shown to be involved in the following diseases: systemic lupus erythematosus (SLE), ${ }^{6}$ autism, ${ }^{7,8}$ hyperactivity, ${ }^{9}$ erythema nodosum in leprosy, ${ }^{10,11}$ postpartum thyroiditis, ${ }^{12}$ diffuse and limited systemic sclerosis, ${ }^{13}$ schizophrenia, ${ }^{14}$ type 1 diabetes mellitus, ${ }^{15}$ congenital adre-

\section{Chromosome 6p - HLA}

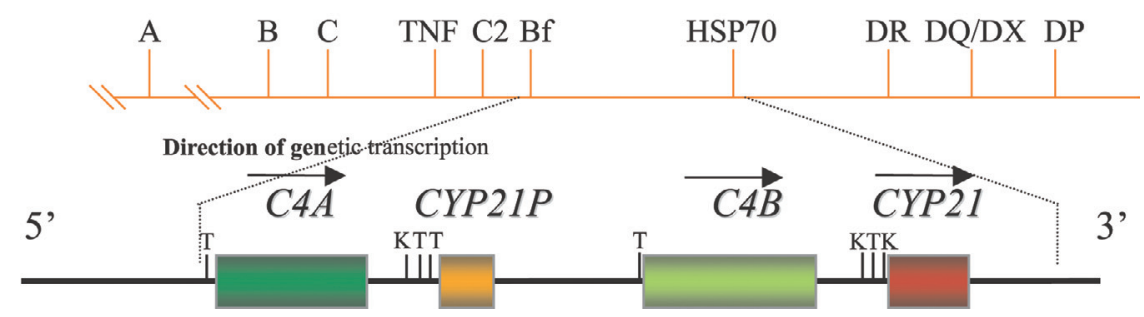

Figure 1 - Schematic representation of human major histocompatibility complex class III. 
nal hyperplasia, ${ }^{16}$ rheumatoid arthritis, ${ }^{17}$ contact dermatitis, ${ }^{3,18}$ infection with encapsulated bacteria, ${ }^{19}$ and sudden infant death ${ }^{4}$ (Table 1).

C4 deficiencies have been associated with an increased susceptibility to bacterial and viral infections, the predisposition to chronic active hepatitis 15 and vitiligo ${ }^{8}$.

However, repeated infections were not always found in people with deficiencies of the components on the classic pathway, exemplifying the importance of the alternative pathway for eliminating the majority of the microorganisms. $^{2}$

A deficiency in the C4A allotype was found to be associated with SLE, postpartum thyroiditis, diffuse sclerosis without the anti-topoisomerase I antibody (ATIA), and limited sclerosis. A deficiency in the C4B allotype was found to be associated with autism, erythema nodosum leprosum, diffuse sclerosis with ATIA, congenital adrenal hyperplasia, type 1 diabetes mellitus, hyperactivity, and rheumatoid arthritis (Table 1). Both C4A and $\mathrm{C} 4 \mathrm{~B}$ allotype deficiencies were not as- sociated with sudden infant death, contact dermatitis and nickel dermatitis. Schizophrenia and infections caused by encapsulated bacteria were not related to $\mathrm{C} 4 \mathrm{~B}$ allotype deficiency and it was not evaluated for $\mathrm{C} 4 \mathrm{~A}$ allotype deficiency.

\section{Autoimmune diseases and C4 allotypes}

The presence of high levels of circulating immune complexes in SLE has been associated with $\mathrm{C} 2$ and $\mathrm{C} 4$ function in the process of removing of these complexes, which suggests that deficiencies of these proteins can occur in autoimmune diseases. ${ }^{2}$ The correlation of high levels of immune complexes and deficiencies of $\mathrm{C} 2$ and $\mathrm{C} 4$ is due to the fact of these proteins are fundamental to the formation of C3-convertase in the classic pathway and to immune complex dissociation.

Studies in different populations that have inheritable total $\mathrm{C} 4$ deficiencies, such as white Western Europeans, Australians, Afro-Americans, Chinese, Japanese, and mixed-race Mexicans, reveal an increased predisposition to SLE in these populations. ${ }^{6,8}$

Homozygous C4A deficiency is observed in from $13 \%$ to $15 \%$ of caucasian patients with SLE and in only $2 \%$ of the normal population, with a relative risk of $17 .{ }^{6}$ Partial or total C4B deficiency also contributes as a risk factor. Total $\mathrm{C} 4$ deficiency has been associated with SLE in more than $80 \%$ of the cases. ${ }^{10}$

Moulds et al. (1993) ${ }^{6}$ verified that C4A and C4B levels in SLE change proportionally to the disease activity. In patients with active disease, the levels of $\mathrm{C} 4 \mathrm{~A}$ and $\mathrm{C} 4 \mathrm{~B}$ increase, while the levels are reduced in the periods without activity, when compared with normal individuals. Additionally, the authors demonstrated that partial deficiencies of one C4 allotype do not modify the total level of serum $\mathrm{C} 4$ protein, which means that heterozygous individuals with $\mathrm{C} 4 \mathrm{~A}$ deficiencies have increased levels of C4B, while heterozygous individuals with $\mathrm{C} 4 \mathrm{~B}$ deficiencies have increased levels of C4A. The authors show in this study that in blacks with SLE, the total levels of $\mathrm{C} 4, \mathrm{C} 4 \mathrm{~A}$, and $\mathrm{C} 4 \mathrm{~B}$ are higher

Table 1 - Literature data associating C4 allotype deficiency and other diseases (C4A and C4B).

\begin{tabular}{|c|c|c|c|c|}
\hline Disease & C4A deficiency & C4B deficiency & Methodology of detection & References \\
\hline Systemic lupus erythematosus & related & related & enzyme-linked immunosorbent assay & Moulds et al. ${ }^{6}$ \\
\hline Autism & not related & related & $\begin{array}{l}\text { enzyme-linked immunosorbent assay } \\
\text { Electrophoresis with immunofixation }\end{array}$ & $\begin{array}{l}\text { Warren et al. } \\
\text { Warren et al. }{ }^{8}\end{array}$ \\
\hline $\begin{array}{l}\text { Erythema nodosum in } \\
\text { Hansen's disease }\end{array}$ & not related & related & $\begin{array}{l}\text { Electrophoresis with immunofixation } \\
\text { and Western blot }\end{array}$ & de Messias et al. ${ }^{10}$ \\
\hline Thyroiditis, postpartum & related & not related & Electrophoresis with immunofixation & Parker et al. ${ }^{12}$ \\
\hline $\begin{array}{l}\text { Diffuse sclerosis With anti- } \\
\text { topoisomerase I antibody }\end{array}$ & not related & related & Electrophoresis with immunofixation & Takeuchi et al. ${ }^{13}$ \\
\hline $\begin{array}{l}\text { Diffuse sclerosis without anti- } \\
\text { topoisomerase I antibody }\end{array}$ & related & not related & Electrophoresis with immunofixation & Takeuchi et al. ${ }^{13}$ \\
\hline Limited sclerosis & related & not related & $\begin{array}{l}\text { Electrophoresis with immunofixation and } \\
\text { polymerase chain reaction }\end{array}$ & Takeuchi et al. ${ }^{13}$ \\
\hline Congenital adrenal hyperplasia & not evaluated & related & Radioimmunoassay & Parlato et al. ${ }^{16}$ \\
\hline Diabetes mellitus type 1 & not evaluated & related & Electrophoresis and immunoprecipitation & Deschamps et al. ${ }^{15}$ \\
\hline Hyperactivity & not related & related & enzyme-linked immunosorbent assay & Warren et al. ${ }^{9}$ \\
\hline Rheumatoid arthritis & not related & related & & Pamela et al. ${ }^{17}$ \\
\hline Sudden infant death & not related & not related & Electrophoresis and polymerase chain reaction & Opdal et al. ${ }^{4}$ \\
\hline Schizophrenia & not evaluated & not related & Polymerase chain reaction & Schroers et al. ${ }^{14}$ \\
\hline S. pneumoniae & not evaluated & not related & Electrophoresis with immunofixation & Cates et al. ${ }^{19}$ \\
\hline \multicolumn{5}{|l|}{ H. influenzae } \\
\hline \multicolumn{5}{|l|}{ N. meningitidis } \\
\hline Contact dermatitis & not related & not related & enzyme-linked immunosorbent assay & Brand et al. ${ }^{3}$ \\
\hline Nickel dermatitis & not related & not related & Electrophoresis with immunofixation & Orecchia et al. ${ }^{18}$ \\
\hline
\end{tabular}


than in Caucasians, independent of disease activity (total C4 level in Afro-European with active disease was close to $40 \mathrm{mg} / \mathrm{dL}$ while in whites was $28 \mathrm{mg} /$ $\mathrm{dL}$ ). This racial difference is more important in SLE evaluation than is the contribution of homozygous or heterozygous C4 deficiency.

Lhotta et al. $(1996)^{20}$ concluded that in glomerulonephritis, the predominance of glomerular C4A deposition is due to a higher affinity of C4A to the proteins of immune complexes. The same affinity is not observed with C4B.

Paimela et al. (1996) ${ }^{17}$ studied 73 cases of rheumatoid arthritis. They found a correlation between the prognostic factor of the disease and the alleles of complement: factor B (Bf) and $\mathrm{C} 4$. Patients with $\mathrm{C} 4 \mathrm{~B}$ null allele (and consequently C4B deficiency) had higher disease activity with more radiological progression than patients with $\mathrm{C} 4 \mathrm{~A}$ null allele or patients without null allele. C4B deficiency was also associated with a higher susceptibility to adverse effects of the antirheumatic therapy. ${ }^{17}$

Takeuchi et al. (1998) ${ }^{13}$ evaluated the contribution of the $\mathrm{C} 4 \mathrm{~A}$ and $\mathrm{C} 4 \mathrm{~B}$ allele polymorphism in the pathogenesis of systemic sclerosis in Japanese patients. A significant increase of $44.4 \%$ in the frequency of C4BQO (null alleles of C4B) in systemic sclerosis with diffuse scleroderma was observed.

In systemic sclerosis with antitopoisomerase I antibodies (ATIA), a $50 \%$ increase of the incidence of C4BQO was also verified. In contrast, the presence of C4AQO was significantly increased in limited scleroderma $(53.8 \%)$ and in systemic sclerosis not associated with the presence of ATIA. They concluded that C4BQO and $\mathrm{C} 4 \mathrm{AQO}$ are independent genetic markers for each clinical subgroup of systemic sclerosis and for the positivity to ATIA.

\section{Endocrine diseases and $\mathrm{C} 4$ allotypes}

Based on the proximity of the $\mathrm{C} 4$ and 21-hydroxylase locci to the class III region of the MHC, Parlato et al. $(1992)^{16}$ studied the relationship between $\mathrm{C} 4$ and enzyme deficiencies that are important in cortisol synthesis. Although there is a lack of evidence in humans, it had been demonstrated in mice that there is hormonal regulation in the production of $\mathrm{Bf}$ and $\mathrm{C} 4$. Despite the few number of cases in the study, these authors suggest that C4B deficiency is associated with DR5+ individuals and low levels of $\mathrm{Bf}$, and C4B deficiency can be related to the congenital adrenal hyperplasia, one of the standard presentations of 21-hydroxylase deficiency. Recently, Gil et al. (2002) $)^{21}$ observed C4 allotype deficiencies associated with 21-hydroxylase deficiency. A duplication of $\mathrm{C} 4 \mathrm{~A}$ or $\mathrm{C} 4 \mathrm{~B}$ with increased serum levels and the deletion of one pair of allotypes, resulting in undetectable levels of them, was also observed.

The association in diabetic relatives between the risk for developing diabetes and $\mathrm{C} 4$ deficiency, especially C4B, was studied by Deschamps et al. (1992). ${ }^{15}$ In a 8 -year prospective study, the authors found a significant risk (relative risk of 112) for siblings of developing type 1 diabetes when they had a DR3,4 genotype, antibodies to islet cells, and a C4B deficiency (C4BQO). In this study, $86 \%$ of individuals with this genotype presented type 1 diabetes, while $25 \%$ without C4B deficiency developed the disease during the follow-up. Among the patients without autoantibodies but with C4B deficiency, 4\% developed the disease. When they compared the individuals, $8.7 \%$ with $\mathrm{C} 4 \mathrm{~B}$ deficiency developed diabetes and only $2.4 \%$ of these individuals without this deficiency developed it, independently of the presence of the autoantibodies. In DR3,4+ and C4B deficient individu- als, 36\% developed the disease compared with only $8 \%$ of the DR3,4+ without $\mathrm{C} 4 \mathrm{~B}$ deficiency. Furthermore, the DR3,4+ individuals with $\mathrm{C} 4 \mathrm{~B}$ deficiency developed diabetes at a younger age than did the group without C4B deficiency $(8.9 \pm 1.42$ years versus $25 \pm 4.9$ years, $p<0.01)$. In contrast, in individuals not DR3,4+ but deficient in C4B, 2\% developed the disease. Therefore, it is reasonable to conclude that the $\mathrm{C} 4 \mathrm{~B}$ deficiency is a risk factor of low importance for type 1 diabetes mellitus when it is not associated with the DR3,4 genotype.

Parker et al. (1996) ${ }^{12}$ evaluated the association between the MHC class III and DQ-MHC molecules in postpartum thyroiditis, and they determined the prevalence of $\mathrm{Bf}, \mathrm{C} 4 \mathrm{~A}$ and $\mathrm{C} 4 \mathrm{~B}$ allotypes in this condition. The following were evaluated: incidence, prevalence, and clinical consequences of postpartum thyroiditis in 2897 pregnant women in South Wales (United Kingdom) between 1983 and 1989. They compared 265 pregnant women with high levels of circulating antithyroid antibodies with other 316 pregnant women having regular levels of the circulating antithyroid antibodies. They verified that postpartum thyroiditis is frequently associated with $\mathrm{C} 4 \mathrm{~A}$ and $\mathrm{Bf}$ deficiencies and not to deficiencies in $\mathrm{C} 4 \mathrm{~B}$.

\section{Psychiatric disorders}

Warren et al. (1994) $)^{7}$ tried to correlate MHC to autism using plasma concentrations of $\mathrm{C} 4$ in autistic patients and their relatives; these data were compared with the results of the plasma concentrations in normal persons. In this study, they observed a significant decrease in the plasma C4B concentration in autistic patients (average of $14.7 \mathrm{~g} / \mathrm{L}$ ) when compared with the normal standard (average of 22.4 $\mathrm{g} / \mathrm{L})$. The plasma concentration of the $\mathrm{C} 4 \mathrm{~B}$ in autistic relatives was also 
found diminished, but it was not significantly lower. C4A concentrations were normal in both groups.

Later $(1995),{ }^{8}$ the same authors evaluated the C4B levels in autistic patients, and they verified that the activation of T DR+ cells was not associated with the patient's age, disproving a notion that in autistic patients, the activation of $\mathrm{T} \mathrm{DR}+$ cells decreases with the aging. However, in this study, it was also verified using DR markers that there were DR+ T cells, indicating T-cell activation, but there was no increase in IL-2 receptor expression in these cells, which is also associated with T-cell activation. These data indicate that T-cell activation is related to the decrease of plasma C4B levels and, perhaps indirectly, to the decrease of MHC class III expression. This conclusion was based on the fact that $\mathrm{C} 4$ allotypes are located on chromosome 6, near the MHC class III and class II regions, which determine the DR genotype of the T lymphocyte (Figure 1). Nevertheless, an association between $\mathrm{C} 4 \mathrm{~A}$ and $\mathrm{T} \mathrm{DR}+$ cells was not found. This study provides strong evidence that an autoimmune process, involving C4B especially, is involved in the genesis of autism, although this disease has an unknown etiology.

The association of decreased $\mathrm{C} 4 \mathrm{~B}$ levels was also observed in children with attention-deficit hyperactivity disorder ${ }^{9}$.

One of the hypotheses regarding the development of schizophrenia is related to C4B deficiency. A study demonstrated an increased expression of HLA-B44 antigen in schizophrenic patients' mothers ${ }^{14}$ and this finding was significant when compared with the control group. It was suggested that the increased expression of HLAB44 in the mothers could induce an abnormal maternal-fetal immune response during the initial stages of pregnancy, and maternal antibodies would challenge a neurological lesion which results in schizophrenic children. ${ }^{6,14}$ Schroers et al. studied 176 patients with schizophrenia and verified that there were no significant differences between these patients and a control group regarding C4B deficiency $(n=145)$. Previous studies ${ }^{7}$ had shown evidence of a relationship between homozygous $\mathrm{C} 4 \mathrm{~B}$ deficiency and schizophrenia. Nevertheless, these authors postulate the possibility that schizophrenia could be associated with a deficiency of a gene close to the $\mathrm{C} 4$ locus, considering the association of schizophrenia with HLA-B44 and its location on the same chromosome.

\section{Dermatological diseases and $\mathrm{C} 4$ allotypes}

de Messias et al. (1993) $)^{10}$ associated C4B deficiency with erythema nodosum leprosum (ENL). Erythema nodosum leprosum results from antibody-mediated reactions and corresponds to the Gell and Coombs type III hypersensitivity. It is hypothesized that these reactions could be linked to bacillar destruction and antigen exposure, resulting in stimulus of antibody production and immune complex formation. These immune complexes activate complement and neutrophil migration, resulting in tissue destruction and vasculitis. The intensity of the ENL phenomenon is associated with the production of tumor necrosis factor (TNF) $\alpha$. In the complete clinical phenotype of ENL, fever, malaise, painful lymphadenitis, erythematous plaques and nodules, neuritis, arthritis, arthralgia, iritis, orchitis, and other findings are observed. The authors evaluated the association between some MHC class III molecules, such as $\mathrm{C} 2, \mathrm{Bf}, \mathrm{C} 4 \mathrm{~A}, \mathrm{C} 4 \mathrm{~B}$, with leprosy in a South Brazilian population. The results demonstrated that there was not an increased C4B expression in leprosy patients with ENL compared with a control group. All the homozygous C4B-deficient patients pre- sented ENL, suggesting that C4B deficiency leads to an abnormal immune response to Mycobacterium leprae. The deficiency in the immune complex clearance results in ENL.

Brand et al. (1994) evaluated C4A, $\mathrm{C} 4 \mathrm{~B}$, and total $\mathrm{C} 4$ levels in the lymph of 2 healthy volunteers after triggering with a contact irritant for 7 days, and they verified that the complement fractions were not involved in the physiopathological mechanism of contact dermatitis, but they were involved in the inflammatory process and in the interactions with the inflammatory cytokines and soluble mediators that arise in the regional lymph nodes. Consequently, they concluded that there is not a special involvement of complement system in the initial pathologic mechanism of contact dermatitis.

Orecchia et al. $(1992)^{18}$ studied the polymorphism of the MHC class III genes in 55 patients of different ages having contact dermatitis. It was not possible to establish a relationship between contact dermatitis stimulated with different allergens and the MHC class III molecules. However, from their findings, they suggested a genetic relationship between MHC and contact dermatitis caused by nickel.

\section{Other diseases}

Opdal et al. (1994) evaluated the involvement of partial deletion of $\mathrm{C} 4$ genes in sudden death of infants. In this study, the authors could not prove a relationship between $\mathrm{C} 4$ deficiency and sudden infant death, but they observed that children with $\mathrm{C} 4 \mathrm{~A}$ and C4B deletion had a higher vulnerability to lethal infections $(p=0.035)$ when compared with normal children.

Cates et al. (1992) ${ }^{19}$ evaluated homozygous $\mathrm{C} 4 \mathrm{~B}$ deficiency and the occurrence of bacteremia or meningitis caused by capsulated microorganisms. Accordingly, they searched for C4B deficiencies in 4 patient groups: patients 
with bacteremia, those with meningitis, those who developed Haemophilus influenzae type b (Hib) disease after Hib polysaccharide vaccination, and patients less than 1 year old with meningitis. Healthy adults served as controls. Of the 257 patients, $2.3 \%$ were homozygous for C4B deficiency compared with $3.7 \%$ in 349 controls. Therefore, an association between homozygous C4B deficiency and meningitis or bacteremia caused by encapsulated bacteria was not observed.

\section{CONCLUSION}

The deficiency of $\mathrm{C} 4$ allotypes has been associated with some diseases: erythema nodosum in leprosy, systemic sclerosis with ATIA, congenital adrenal hyperplasia with DR5 genotype, type 1 diabetes mellitus with DR3,4 genotype, and diabetes mellitus with anti-islet cell antibodies. Some association has also been noted between $\mathrm{C} 4 \mathrm{~B}$ and the activity in some autoimmune diseases, such as SLE, or in diseases with a supposed autoimmune component in their genesis, such as autism.

Regarding C4A, the studies demonstrated an association with postpartum thyroiditis and limited sclerosis and systemic sclerosis without ATIA; however, with $\mathrm{C} 4 \mathrm{~A}$ as for $\mathrm{C} 4 \mathrm{~B}$, the studies are concentrated in isolated populations, and some studies could not be reproduced by other authors, such as those concerning schizophrenia.

Thus, we conclude that additional studies using standardized methods for determining allotypes and genotypes are required to characterize the association between $\mathrm{C} 4$ deficiencies and human diseases.

\section{ACKNOWLEDGEMENTS}

Dr. Maricilda Mello for the schematic representation of HLA and Dr. Registila Libania Beltrame for the support of the development of this study.

\section{RESUMO}

SAMANO EST e col. O envolvimento dos alótipos de $\mathrm{C} 4$ na patogênese das doenças humanas. Rev. Hosp. Clín. Fac. Med. S. Paulo 59(3): 138-144, 2004.

O sistema complemento constitui um importante sistema de defesa humoral, exercendo papel relevante na resposta contra agentes microbianos, no controle da resposta inflamatória e na depuração de imunocomplexos. A ativação da via clássica é dependente da formação do complexo antígenoanticorpo. O componente $\mathrm{C} 4$ do complemento participa da etapa inicial de ativação desta via e a sua expressão é determinada por dois alótipos : C4A e C4B. A deficiência dos alótipos de C4 tem sido relacionada a várias doenças.
O objetivo do presente estudo foi avaliar os dados de literatura que descrevem as deficiências específicas de $\mathrm{C} 4 \mathrm{~A}$ e C4B com a finalidade de caracterizar seu significado clínico.

Foi realizada uma ampla revisão bibliográfica através do MEDLINE e LILACS, avaliando-se os dados de literatura. Excluiu-se estudos com a avaliação de $\mathrm{C} 4$ total sem a análise dos alótipos e relatos de caso isolados de deficiência total de $\mathrm{C} 4$.

Verificou-se que a deficiência dos alótipos de C4 está relacionada com algumas doenças: hanseníase, esclerose sistêmica com anticorpos anti-topoisomerase I, hiperplasia adrenal congênita intermediária com genótipo DR5, diabetes mellitus tipo 1 com genótipo DR3,4 e diabetes mellitus tipo 1 com anticorpos anti-células das ilhotas. Também foram observadas algumas associações entre C4B e doenças auto-imunes como lupus eritematoso sistêmico, ou que se supõe terem um componente auto-imune como o autismo. Estudos demonstraram associações do $\mathrm{C} 4 \mathrm{~A}$ com tireoidite pós-parto, esclerose limitada e esclerose sistêmica sem anticorpos anti-topoisomerase I. Porém, os estudos dos alótipos de $\mathrm{C} 4$ se concentraram em populações isoladas e alguns destes não conseguiram ser reproduzidos por outros autores.

UNITERMOS: C4A. C4B. C4. Complemento. Deficiência de complemento. Alótipos de C4.

\section{REFERENCES}

1. Kirschfink M, Grumach AS. Deficiências de Complemento. In: GRUMACH AS. Alergia e Imunologia na Infância e na Adolescência. São Paulo, Atheneu, 2001, 497-514.
2. Isaac L. Sistema complemento. In: Calich V, Vaz C - Imunologia. $1^{\mathrm{a}}$ ed. Rio de Janeiro, Revinter, 2001, $99-118$. 
Involvement of $\mathrm{C} 4$ allotypes in the pathogenesis of human diseases Samano EST et al.

3. Brand CU, Späth PJ, Hunziker T, Limat A, Braathen LR. Complement profiles in human skin lymph during the course of irritant contact dermatitis. Arch Dermatol Res 1994, 286 (7): $359-363$.

4. Opdal SH, Vege $\AA$, Saugstad OD, Rognum TO. Is partial deletion of the complement $\mathrm{C} 4$ genes associated with sudden infant death? Eur J Pediatr, 1994; 153 (4): 287-290.

5. Finco O, Li S, Cuccia M, Rosen FS, Carroll MC. Structural differences between the two human complement $\mathrm{C} 4$ isotypes affect the humoral immune response. J. Exp. Med., 1992; 175 (2) $537-543$.

6. Moulds JM, Warner NB, Arnett FC. Complement component C4A and C4B levels in systemic lupus erythematosus: quantitation in relation to $\mathrm{C} 4$ null status and disease activity. J Rheum, 1993; 20 (9) :3, 443-447.

7. Warren RP, Burger RA, Odell D, Torres AR, Warren NWL. Decreased plasma concentrations of the $\mathrm{C} 4 \mathrm{~B}$ complement protein in autism. Arch Pediatr Adolesc Med, 1994; 148 (2): 180-183.

8. Warren RP, Yonk J, Burger RW, Odell D, Warren WL. DR-positive $\mathrm{T}$ cells in autism: association with decreased plasma levels of the complement C4B protein. Neuropsychobiology, 1995; 31(2):53-57.

9. Warren RP, Odell JD, Warren Wl, Burger RA, Maciulis A, Torres AR. Is decreased blood plasma concentration of the complement $\mathrm{C} 4 \mathrm{~B}$ protein associated with attention-deficit hyperactivity disorder? J Am Acad Child Adolesc Psychiatry, 1995; 34(8):1009-1014.

10. De Messias IJT, Santamaria J, Brenden M, Reis A, Mauff G. Association of $\mathrm{C} 4 \mathrm{~B}$ deficiency $(\mathrm{C} 4 \mathrm{~B} * \mathrm{Q} 0)$ with erythema nodosum in leprosy. Clin Exp Immunol, 1993; 92 (2):284287.

11. Sampaio APS, Rivitti EA. Dermatologia. $2^{\mathrm{a}}$ ed. São Paulo, Artes Médicas, 2000, p-479-480.

12. Parker AB, Darke C, Othman S, Thomas M, Young N, Richards $\mathrm{CJ}$, et al. Major histocompatibility complex class II and complement polymorphisms in postpartum thyroiditis. Eur $\mathbf{J}$ Endocrinol, 1996; 134 (4):449-453.
REV. HOSP. CLÍN. FAC. MED. S. PAULO 59(3):138-144, 2004

13. Takeuchi F, Nabeta H, Hong GH, Matsuta K, Tokunaga K, Tanimoto K, et al. C4A and C4B null alleles are genetic markers of different types of systemic sclerosis in Japanese patients. Clin Exp Rheumatol, 1998; 16 (1):55-60.

14. Schroers R, Nöthen MM, Rietschel M, Albus M, Maier W, Scwab $\mathrm{S}$, et al. Investigation of complement $\mathrm{C} 4 \mathrm{~B}$ deficiency in schizophrenia. Hum Hered, 1997; 47 (5):279-282.

15. Deschamps I, Boitard C, Hors J, Busson M, Marcelli-Barge A, Mogenet A, et al.. Life table analysis of the risk of type 1 (insulin-dependent) diabetes mellitus in siblings according to islet cell antibodies and HLA markers. Diabetologia, 1992; 35 (10):951-957.

16. Parlato F, Pisano G, Misiano G, Cosentini E, Cacciapuoti C, Cavalcanti Mr, et al. HLADR5 and C4BQO high frequency and antinuclear antibodies positivity in patients with 21 hydroxylase deficiency from Campania region. J. Endocrinol. Invest., 1992;15 (6):429-436.

17. Pamela L, Leirisalo-Repo M, Lokki ML, Koskimies S. Prognostic significance of complement alleles $\mathrm{Bf}$ and $\mathrm{C} 4$ in early rheumatoid arthritis. Clin Rheumatol, 1996; 15(6):594-598.

18. Orecchia G, Perfetti L, Finco O, Dondi E, Cuccia M. Polymorphisms of HLA class III genes in allergic contact dermatitis. Dermatology, 1992; 184 (4):254-259.

19. Cates KL, Densen P, Lookman JC, Levine Rp. C4B deficiency is not associated with meningitis or bacteremia with encapsulated bacteria. J Infect Dis, 1992; 165 (5):942-944.

20. Lhotta K, Schlogi A, Kronenberg F, Joannidis M, Konig P. Glomerular deposition of the complement C4 isotypes C4A and C4B in glomerulonephritis. Nephrol Dial Transplant, 1996; 11(6):1024-1028.

21. Guerra JG, Nascimento SRD, Araujo M, Condino NA, Lemos MSHV, Arruk V, et al. Congenital adrenal hyperplasia due to classical 21 hydroxylase deficiency (CYP21): possible association with $\mathrm{C} 4$ deficiency. Intern Immunopharmacol, 2002.; 2(9):1380-1381. 